\title{
TINDAKAN KEMOTERAPI DENGAN TINGKAT KECEMASAN PADA KLIEN KANKER DI RUMAH SAKIT GRANDMED LUBUK PAKAM TAHUN 2021
}

\author{
Kuat Sitepu ${ }^{1 *}$, Adi Arianto1 ${ }^{\text {, Luci Riani Br Ginting }}{ }^{2}$, Henni Dawati Damanik ${ }^{1}$ \\ ${ }^{1}$ Program Studi S1 Keperawatan, Institut Kesehatan Medistra Lubuk Pakam \\ ${ }^{2}$ Program Studi S1 Kesehatan Masyarakat, Institut Kesehatan Medistra Lubuk Pakam
}

\author{
Jln. Sudirman No.38 Lubuk Pakam, Kabupaten Deli Serdang, \\ Sumatera Utara - Indonesia \\ *email korespondensi author: ksitepu3@gmail.com
}

\section{DOI $10.35451 /$ jpk.v1i1.767}

\begin{abstract}
Abstrak
Kemoterapi adalah proses pengobatan yang memakai preparat antineoplastik menggunakan tujuan membunuh sel kanker menggunakan fungsi dan reproduksi seluler. Kanker menggunakan adanya pembelahan sel yang tidak terkendali dan selsel yang menyerang jaringan biologis lainnya, baik menggunakan pertumbuhan langsung di jaringan invasi atau menggunakan migrasi sel ketempat yang jauh (metastasis). Penyakit kanker ini merupakan penyakit yang tidak menular dan menjadi masalah kesehatan masyarakat, baik dunia maupun di Indonesia. tujuan: Untuk mengetahui hubungan tindakan kemoterapi dengan tingkat kecemasan pada klien kanker di Rumah Sakit Grandmed Lubuk Pakam tahun 2021. Metode: analisis data hasil pengabdian ini menggunakan design kuantitatif dengan jenis survey analitik. pengabdian ini menggunakan design dengan menggunakan cross sectional yaitu adalah jenis studi observasi yang menganalisis data dari suatu populasi. Hasil pengabdian ini didapatkan nilai $p=0,00$. Berarti $p$ value $<0.05$, maka ada hubungan tindakan kemoterapi dengan tingkat kecemasan pada klien kanker di Rumah Sakit Grandmed Lubuk Pakam tahun 2021. Kesimpulan: tindakan kemoterapi akan memberikan tingkat kecemasan yang berbeda-beda pada setiap pasien yang menjalaninya, tergantung dari sikap mereka menerima penyakitnya serta adanya ilmu pengetahuan yang ada tentang penyakit kanker yang akan di obati dengan cara di kemoterapi. Saran : Bagi Tempat pengabdian: Diharapkan dapat menambah wawasan untuk perawat lainnya untuk lebih memaksimalkan tindakan yang akan dilakukan.
\end{abstract}

Kata kunci :tindakan kemoterapi, tingkat kecemasan, klien kanker

\begin{abstract}
Chemotherapy is a treatment process that uses antineoplastic preparations with the aim of killing cancer cells and slowing the growth of cancer cells by disrupting cellular function and reproduction. Cancer is characterized by uncontrolled cell division and the ability of these cells to invade other tissues, either by direct growth into adjacent tissue (invasion) or by migration of cells to the place that is far away (metastasis). Cancer is one of the non-communicable diseases that is a public health problem, both in the world and in Indonesia. Research objectives: To determine the relationship between chemotherapy and anxiety levels in cancer clients at Grandmed Lubuk Pakam Hospital in 2021. Research methods: This study used a quantitative research design with the type of analytical survey. This study used a cross-sectional design, which is a type of observational study that analyzes data from a population. the research results obtained $p$ value $=0.00$. It means that the $p$ value $<0.05$, then there is a relationship between chemotherapy measures and anxiety levels in cancer clients at Grandmed Lubuk Pakam Hospital in 2021. Conclusion: chemotherapy will provide different levels
\end{abstract}


Received: 19 June 2021 :: Accepted: 24 June 2021 :: Published: 30 June 2021

of anxiety for each patient undergoing it, depending on their attitude to accept the disease. as well as the existing knowledge about cancer that will be treated by chemotherapy. Suggestion: For Research Sites: It is hoped that it can add insight to other nurses to further maximize the actions to be taken.

Keywords: chemotherapy measures, anxiety level, cancer clients

\section{Pendahuluan}

Kanker merupakan penyakit yang ditandai dengan adanya pembelahan sel yang tidak terkendali dan kemampuan sel-sel tersebut untuk menyerang jaringan biologis lainnya, baik dengan pertumbuhan langsung di jaringan yang bersebelahan (invasi) atau dengan migrasi sel ketempat yang jauh (metastasis). Penyakit kanker merupakan salah satu penyakit tidak menular yang menjadi masalah kesehatan masyarakat, baik dunia maupun di Indonesia. Namun kanker merupakan pembunuh no. 2 setelah penyakit kardiovaskuler yang menyebabkan kematian sebesar $12 \%$ kematian di dunia. (Adipo et al. 2016).

Organisasi Kesehatan Dunia World Health Organization (WHO) memperkirakan bahwa 12 juta orang diseluruh dunia terkena kanker setiap tahun dan 7,6 juta meninggal karena kanker. Menurut data di Eropa, terdapat sekitar 421.000 kasus baru dan hampir 90.000 kematian pada tahun 2008, dibandingkan di Amerika Serikat tercatat lebih dari 190.000 kasus baru dan 40.000 kematian (Soebachman, 2011 dalam Adipo et all 2016).

Diperkirakan aka nada 1,6 juta kasus kanker dan 1,1 juta kematian akibat kanker, terutama di Asia Tenggara pada tahun 2012 di Indonesia, kanker disebabkan oleh stroke, TBC, tekanan darah tinggi, trauma, penyakit perinatal dan diabetes. Menurut Sistem Informasi Rumah Sakit (SIRS), jenis kanker tertinggi di RS seluruh Indonesia pasien rawat inap tahun 2008 adalah kanker payudara (18,4\%) (Depkes, 2010 dalam Adipo, 2016).

Prosedur medis untuk mengobati kanker meliputi pembedahan, terapi radiasi, dan kemoterapi. Kemoterapi adalah pengobatan sistemik. Dengan kata lain, obat menyebar ke seluruh tubuh hingga mencapai sel kanker yang telah menyebar di tempat lain.

Efek kemoterapi mempengaruhi kesehatan sel dan sel kanker dan dapat menimbulkan banyak efek samping. Efek samping pada pasien yang menerima kemoterapi naturopati termasuk mual, muntah, gangguan pencernaan, diare, kerusakan kulit, rambut rontok, dan kerusakan sumsum tulang belakang, yang mengurangi produksi sel darah merah, menyebabkan anemia dan kekebalan melemah. Pelanggan merasa takut, takut dan takut. (Yudono, 2019).

Pasien yang menerima kemoterapi untuk pertama kalinya sering berisiko mengalami kecemasan tingkat tinggi dan meremehkan kemampuan mereka. Pasien takut atau takut akan efek samping kemoterapi (Yudono, 2019).

Efek psikis yang paling sering terjadi dari kemoterapi adalah kecemasan. Kecemasan adalah suatu perubahan yang ambigu dan difus atau kecemasan psikososial yang berhubungan dengan kecemasan, ketidakberdayaan, kecemasan, dan perasaan bahwa penyakitnya masih tetap terancam, bingung, panik, dan tertekan (Theophilus, 2015). Seseorang dengan kanker mengalami stres psikologis, seperti informasi kanker yang mereka terima setelah didiagnosis menderita kanker. Seseorang yang 
Received: 19 June 2021 :: Accepted: 24 June 2021 :: Published: 30 June 2021

didiagnosis menderita kanker dijatuhi hukuman mati, dan itu hanya masalah waktu. Keadaan kecemasan yang umum termasuk insomnia, kesulitan berkonsentrasi, kehilangan nafsu makan, keputusasaan yang ekstrem, dan kurangnya antusiasme untuk hidup. Ini adalah reaksi emosional umum yang dapat terjadi ketika dokter mendiagnosis penyakit serius (kronis) seperti kanker, seperti penolakan, kecemasan, atau depresi (Nurpeni, 2017). Kecemasan merupakan reaksi umum terhadap perubahan status kesehatan yang terjadi sebagai ancaman, ancaman umum termasuk mual, muntah parah demam, pendarahan, rambut rontok dan dan lainlain. Diperkirakan jumlah mereka yang menderita kecemasan baik akut maupun kronik mencapai $5 \%$ dari jumlah penduduk, denganperbandingan antara wanita dan peria 1: 1000, dan diperkirakan antara 2\%sampai $4 \%$ di antara penduduk di suatu saat dalam kehidupanya pernah mengalami cemas (Dadang Hawari, 2011 dalam Juliandi 2017).

Pasien kanker seringkali takut akan kurangnya informasi tentang kanker dan kesalahpahaman tentangnya. Ketakutan akan kanker membutuhkan psikologis dan kemoterapi, dan jika perlu, bantuan psikolog, ahli agama, atau tokoh masyarakat (Yunitasari, 2016).

Di Rumah Sakit Grandmed banyak pasien kanker yang mengalami kecemasan karena keadaan yang dialaminya.Banyak pasien kanker yang merasa takut untuk dilakukan tindakan kemoterapi, mereka takut mati setelah dilakukan tindakan kemoterapi. Mereka tidak tau apa manfaat dari tindakan kemoterapi, bagi pasien, tindakan kemoterapi adalah tindakan akhir dari penyakit kanker. Data yang di dapat saat peneliti melakukan survey awal banyaknya pasien kanker di ruang 5D sebanyak 30 orang. Terdiri atas 5 orang yang sudah 3 kali mendapatkan tindakan kemoterapi dan 25 orang yang belum pernah kemoterapi, tetapi mengalami penyakit kanker, kanker yang dialami pasien terdiri dari kanker mamae, kanker serviks, juga leukemia (kanker darah). Banyak pasien kanker yang di rawat di Rumah Sakit Grandmed memilih untuk hanya diberikan tindakan biasa seperti hanya di rawat inap dan hanya di infus.Hal ini membuat peneliti tertarik untuk melakukan pengabdian tentang hubungan tindakan kemoterapi dengan tingkat kecemasan pada klien kanker.

\section{Metode}

Data hasil kegiatan pengabdian masyarakat ini diolah menggunakan design kuantitatif dengan jenis survey analitik. pengabdian ini menggunakan design dengan menggunakan cross sectional yaitu adalah jenis studi observasi yang menganalisis data dari suatu populasi. (Sugiyono,2018). Sasaran penyuluhan ini sebanyak 30 orang.

\section{Hasil dan Pembahasan Hasil}

Distribusi tentang Hubungan tindakan kemoterapi pada klien kanker di Rumah Sakit Grandmed Lubuk Pakam tahun 2021 dapat dilihat pada tabel 1 dibawah ini:

Tabel 1 Distribusi Tindakan Kemoterapi di Rumah Sakit Grandmed Lubuk Pakam tahun 2021.

\begin{tabular}{lccc}
\hline $\begin{array}{l}\mathbf{N} \\
\mathbf{0}\end{array}$ & $\begin{array}{c}\text { Tindakan } \\
\text { kemoterapi }\end{array}$ & $\begin{array}{c}\text { Frekue } \\
\text { nsi (n) }\end{array}$ & $\begin{array}{c}\text { Persent } \\
\text { ase } \\
(\%)\end{array}$ \\
\hline 1 & $\begin{array}{c}\text { Tidak } \\
\text { dilakukan }\end{array}$ & 19 & 63,3 \\
2 & Dilakukan & 11 & 36,7 \\
\hline \multicolumn{2}{l}{ Total } & $\mathbf{3 0}$ & $\mathbf{1 0 0 , 0}$ \\
\hline
\end{tabular}

Dari tabel 1 dapat dilihat bahwa tindakan kemoterapi yang tidak dilakukan yaitu sebanyak 19 orang $(63,3 \%)$, dan tindakan kemoterapi yang dilakukan yaitu sebanyak 11 orang $(36,7 \%)$. 
Received: 19 June 2021 :: Accepted: 24 June 2021 :: Published: 30 June 2021

Dari tabel 2 dapat dilihat bahwa tingkat kecemasan yang ringan yaitu sebanyak 1 orang $(3,3 \%)$, tingkat kecemasan yang sedang yaitu sebanyak 10 orang $(33,3 \%)$, dan tingkat kecemasan yang berat yaitu sebanyak 19 orang $(63,3 \%)$.

Tabel 2 Distribusi Tingkat Kecemasan di Rumah Sakit Grandmed Lubuk Pakam tahun 2021

\begin{tabular}{llcc}
\hline $\mathbf{N}$ & $\begin{array}{l}\text { Tingkat } \\
\text { Kecema } \\
\text { san }\end{array}$ & $\begin{array}{c}\text { Frek } \\
\text { uensi } \\
(\mathbf{n})\end{array}$ & $\begin{array}{c}\text { Persentas } \\
\text { e } \mathbf{( \% )}\end{array}$ \\
\hline 1 & Ringan & 1 & 3,3 \\
2 & Sedang & 10 & 33,3 \\
3 & Berat & 19 & 63,3 \\
\hline Total & $\mathbf{3 0}$ & $\mathbf{1 0 0 , 0}$ \\
\hline
\end{tabular}

Distribusi Hubungan tindakan kemoterapi dengan tingkat kecemasan pada klien kanker di Rumah Sakit Grandmed Lubuk Pakam tahun 2021 dapat dilihat pada tabel 3.

Tabel 3 Hubungan tindakan kemoterapi dengan tingkat kecemasan pada klien kanker di Rumah Sakit Grandmed Lubuk Pakam tahun 2021.

\begin{tabular}{|c|c|c|c|c|c|}
\hline \multirow{3}{*}{$\begin{array}{c}\text { Tingkat } \\
\text { kecema } \\
\text { san }\end{array}$} & \multicolumn{4}{|c|}{ Tindakan kemoterapi } & \multirow{3}{*}{$\begin{array}{l}p \\
\text { Val } \\
\text { ue }\end{array}$} \\
\hline & \multicolumn{2}{|c|}{$\begin{array}{c}\text { Tidak } \\
\text { dilakukan }\end{array}$} & \multicolumn{2}{|c|}{ Dilakukan } & \\
\hline & $\mathrm{F}$ & $\%$ & $f$ & $\%$ & \\
\hline Ringan & 0 & 0,0 & 1 & 10.0 & \multirow{4}{*}{$\begin{array}{l}0,0 \\
00\end{array}$} \\
\hline Sedang & 2 & 20,0 & 8 & 80 & \\
\hline Berat & 17 & 89,5 & 2 & 10,5 & \\
\hline Total & 19 & 100 & 11 & 100 & \\
\hline
\end{tabular}

dari 1 orang pasien yang mempunyai tingkat kecemasan ringan didapatkan 1 orang $(100,0 \%)$, dilakukan tindakan kemoterapi di Rumah Sakit, dan 0 orang $(0,0 \%)$, tidak dilakukan tindakan kemoterapi di Rumah Sakit. Dari 10 orang pasien yang mempunyai tingkat kecemasan sedang, didapatkan 8 orang $(80,0 \%)$ dilakukan tindakan kemoterapi di Rumah Sakit, dan 2 orang pasien $(20,0 \%)$, tidak dilakukan tindakan kemoterapi di Rumah Sakit, dan 19 orang pasien $(100,0 \%)$ yang mempunyai tingkat kecemasan berat, didapatkan 2 orang pasien $(10,5 \%)$ dilakukan tindakan kemoterapi, dan 17 orang pasien $(89,5 \%)$, tidak dilakukan tindakan kemoterapi. Hasil analisis untuk mengetahui hubungan tindakan kemoterapi dengan tingkat kecemasan pada klien kanker di Rumah Sakit Grandmed Lubuk Pakam tahun 2021. Didapatkan nilai $p=0,00$. Berarti $p$ value $<0.05$, maka ada Hubungan tindakan kemoterapi dengan tingkat kecemasan pada klien kanker di Rumah Sakit Grandmed Lubuk Pakam tahun 2021.

\section{Pembahasan}

\begin{tabular}{llr} 
Kemoterapi adalah proses & \multicolumn{1}{c}{ pelalui } \\
penghancuran sel kanker & melapi \\
regenerasi sel. Kemoterapi & adalah \\
metode pengobatan kanker & dengan
\end{tabular} meresepkan zat/obat yang membunuh sel kanker (Juliandi, 2016). Menurut Yudono (2019), analisis hubungan antara kecemasan dan faktor-faktor yang mempengaruhi tingkat kecemasan yang diamati pada p-value 0,000 menunjukkan bahwa hasil stadium kanker dikaitkan dengan tingkat kecemasan. Berdasarkan dari hasil pengabdian didapatkan bahwa tindakan kemoterapi yang tidak dilakukan yaitu sebanyak 19 orang $(63,3 \%)$, dan tindakan kemoterapi yang dilakukan yaitu sebanyak 11 orang $(36,7 \%)$. Menurut penelitian dari Juliandi, 2016, dengan judul pengaruh tingkat kecemasan pasien carsinoma paru dalam menjalani tindakan kemoterapi di ruang Kemoterapi Rsud Dr. Zoelham Binjai Tahun 2016, menyatakan bahwa tingkat pengetahuan dan pendidikan seseorang mempengaruhi kecemasan, karena bila responden memiliki pendidikan SMA masih memiliki tingkat kecemasan yang tinggi. karena pendidikan tidak mutlak menjamin bahwa orang yang berpendidikan akan mampu menghadapi kecemasan yang ada, begitu juga dengan pengetahuan, bila pengetahuan responden responden yang berpengetahuan cukup, Dalam hal ini semakin banyak pengetahuan, sumber 
Received: 19 June 2021 :: Accepted: 24 June 2021 :: Published: 30 June 2021

informasi dan pengalaman seseorang maka semakin rendah tingkat kecemasan yang dialami.

Tindakan kemoterapi yang dilakukan oleh responden untuk pertama kali dilakukan, akan memberikan dampak kecemasan yang lebih tinggi pada responden, karena ketidak tau an responden untuk efek dari tindakan kemoterapi yang akan dilakukan. Akan memberikan respon negatif dari responden untuk tidak mau dilakukan tindakan kemoterapi.Kemoterapi tidak dilakukan dikarenakan banyak pasien yang dirawat dengan masalah kanker merasa khawatir akan tindakan tersebut yang akan berpengaruh pada kondisinya. karena efek dari obat kemoterapi dapat membuat pasien mengalami mual, muntah, kulit kering serta rasa tidak nyaman pasca dilakukan tindakan kemoterapi. Asumsi peneliti bahwa pasien yang belum menjalani kemoterapi kebanyakan sudah merasa takut terlebih dahulu sebelum menjalankan proses dari tindakan kemoterapi dikarenakan banyak yang mendengar kabar dari banyak orang yang menyatakan bahwa tindakan kemoterapi itu sangat berbahaya dan akan membuat kondisi pasien menjadi sangat lemah setelah dilakukan tindakan tersebut.

Berdasarkan hasil pengabdian yang menggunakan uji chi-square didapatkan Hasil analisis untuk mengetahui Hubungan tindakan kemoterapi dengan tingkat kecemasan pada klien kanker di Rumah Sakit Grandmed Lubuk Pakam tahun 2021. Didapatkan nilai $p=0,00$. Berarti $p$ value < 0.05, maka ada Hubungan tindakan kemoterapi dengan tingkat kecemasan pada klien kanker di Rumah Sakit Grandmed Lubuk Pakam tahun 2021.

Hal ini sesuai dengan Hasil pengabdian yang didukung oleh penelitian Teovilus, (2015), bahwa Hasil uji Kendall's Tau diperoleh tingkat signifikansi sebesar 0,00 ( $\operatorname{sig}<0,05)$. Hal ini berati Ho ditolak dan Ha diterima, maka dapat disimpulkan bahwa ada hubungan yang signifikan antara tingkat pengetahuan pasien kanker tentang kemoterapi dengan kecemasan dalam menjalani tindakan kemoterapi di RSUD Panembahan Senopati Bantul.

Kecemasan (anxiety) merupakan reaksi normal terhadap ancaman stress dan bahaya, baik yang nyata maupun yang dibayangkan. Kecemasan adalah reaksi umum terjadi terhadap perubahan status kesehatan yang dianggao sebagai ancaman, ancaman umum termasuk mual, muntah parah, demam, perdarahan, rambut rontok dan lain-lain. Kecemasan pasien akan menghadapi pengobatan atau menghadapi kematian bisa berakibat terganggunya pengobatan. (Juliandi, 2017).

Adaptasi seseorang diperlukan untuk mempersiapkan kondisi fisik dan psikologis selama menjalani pengobatan, $\mathrm{Hal}$ ini dapat meningkatkan kecemasan yang dirasakan karena adaptasinya buruk, dan biasanya responden yang memiliki penyakit kanker dengan stadium 2 dan 3, dimana stadium tersebut membuat pasien merasa cemas karena merasa takut akan penyakitnya yang akan menggangu kesehatan.

Dukungan keluarga dengan dukungan emosional (perhatian, cinta, empati) dukungan rasa syukur, dan dukungan aktif dukungan penghargaan (menghargai, umpan balik), dukungan informasi (saran, nasehat, informasi) maupun dalam bentuk dukungan instrumental (bantuan tenaga, dana, dan waktu). Pasien yang menerima dukungan terutama dari keluarga akan membuat pasien merasa nyaman, diperhatikan dalam menjalani kemoterapi.

Masalah kesehatan mental responden memiliki dampak yang signifikan terhadap kondisi pasien saat menunggu diagnosis, pemeriksaan medis atau laporan efek samping pengobatan, atau menunggu hasil tes. Sulit bagi 
Received: 19 June 2021 :: Accepted: 24 June 2021 :: Published: 30 June 2021

pasien kanker untuk memahami kondisi ini karena kondisi kanker ini dan pengobatannya dapat menyebabkan stres tertentu serta pengkondisian fisik dan psikologis individu.

Pada akhirnya tindakan kemoterapi akan memberikan tingkat kecemasan yang berbeda-beda pada setiap pasien yang menjalaninya, tergantung dari sikap mereka menerima penyakitnya serta adanya ilmu pengetahuan yang ada tentang penyakit kanker yang akan di obati dengan cara di kemoterapi.

\section{Kesimpulan}

Berdasarkan hasil dan pembahasan, kesimpulan dengan mengetahui hubungan tindakan kemoterapi dengan tingkat kecemasan pada klien kanker di Rumah Sakit Grandmed Lubuk Pakam tahun 2021. ini adalah tindakan kemoterapi dengan tingkat kecemasan pada klien kanker di Rumah Sakit Grandmed Lubuk Pakam tahun 2021, bahwa Didapatkan nilai $p=$ 0,00 . Berarti $p$ value $<0.05$, maka ada Hubungan tindakan kemoterapi dengan tingkat kecemasan pada klien kanker di Rumah Sakit Grandmed Lubuk Pakam tahun 2021.

\section{Ucapan Terima Kasih}

Ucapan terima kasih yang sebesarbesarnya kepada Institut Kesehatan Medistra Lubuk Pakam, Lembaga Penelitian dan Pengabdian kepada Masyarakat Institut Kesehatan Medistra Lubuk Pakam, Direktur Rumah Sakit Grandmed Lubuk Pakam, dan semua pihak yang telah mendukung kegiatan PKM ini yang tidak dapat disebutkan satu per satu.

\section{Daftar Pustaka}

Adipo.(2016). Hubungan dukungan keluarga dengan tingkat kecemasan pasien yang menjalani kemoterapi di ruang anyelir rsud arifin achmad Provinsi Riau.
Apriyani. (2017).The Predictors Of Psychological Status Among Primary Breast Cancer Patients In Japan.vhttp://www.scirp.org/journ al/ojn.

Fayed, L. (2019).Hubungan dukungan keluarga dengan tingkat kecemasan pasien pre operasi di ruangan RB2 RSUP HAM.

Juliandi. (2017). Pengaruh tingkat kecemasan pasien carsinoma paru dalam menjalani tindakan kemoterapi di ruang kemoterapi rsud dr. zoelham binjai tahun 2016 .vol 11 nmr 3 Januari-April 2017.

Kemp, Charles. (2010). Klien Sakit Terminal. Seri AsuhanKeperawatan. Edisi 2. EGC

Lubis, N, Hasnida. (2009).Terapi perilaku kognitif pada pasien kanker. Medan - USU Press, 2009.

Lutfa.(2016). Faktor-faktor yang mempengaruhi kecemasan pasien dalam tindakan kemoterapi di Rumah Sakit dr.Moewardi Surakarta.

Nurpeni et all. (2017). Hubungan dukungan keluarga dengan tingkat kecemasan pada pasien kanker payudara (ca mammae) di ruang angsoka III RSUP sanglah denpasar.

Stuart. (2017). Buku Ajar Patofisiologi. Jakarta: EGC.

Yunitasari.(2016). Hubungan beberapa demografi dengan tingkat kecemasan pasien pasca diagnosis kanker di RSUP Dr. Kariadi Semarang.

Yudono, D, T. (2019).Analisis faktorfakor yang mempengaruhi kecemasan pasien ca mamae dengan tindakan kemoterapi.

Sulistyawati.(2016). Hubungan Dukungan keluarga dengan tingkat kecemasan pasien kanker ginekologi yang menjalani kemoterapi di ruang cempaka timur RSUP Sanglah Denpasar.

Teovilus.(2015). Hubungan pengetahuan pasien tentang kemoterapi dengan kecemasan dalam menjalani tindakan kemoterapi di rsud panembahan senopati bantul.Media Ilmu Kesehatan Vol. 4, No. 1, April 2015. 